\title{
KETERKAITAN ATMOSPHERIC, JOY DAN CUSTOMER LOYALTY PENGUNJUNG TRANS STUDIO BANDUNG
}

\author{
Dewi Anggraeni \\ Dudi Anandya \\ Silvia Margaretha \\ Fakultas Bisnis dan Ekonomika Universitas Surabaya \\ Raya Kalirungkut Surabaya 60293 \\ Email: samkidud@gmail.com
}

\begin{abstract}
Abstrak
Penelitian ini bertujuan untuk mengetahui dan menganalisis pengaruh atmospheric terhadap customer loyalty melalui joy pada pengunjung Trans Studio Bandung. Penelitian ini menggunakan SEM dengan LISREL 8.7. Teknik pengambilan sampel yang digunakan adalah convenience sampling. Penelitian ini menggunakan survei melalui kuesioner. Jumlah sampel sebanyak 120 responden. Hasil dari penelitian ini menunjukkan satu dari tiga variabel atmospheric berpengaruh terhadap variabel joy yaitu design, dua variabel lainnya yaitu ambience dan interaction tidak berpengaruh terhadap joy dan joy berpengaruh terhadap customer loyalty.
\end{abstract}

Kata Kunci: Atmospheric, Joy, Persepsi, Customer Loyalty

\begin{abstract}
This research aimed to find and analyze the influence of atmospheric to customer loyalty through joy on Trans Studio Bandung visitors. This research used SEM with LISREL 8.7. The sampling technique used was convenience sampling. This study used a survey through the questionnaire. Number of sample was 120 respondents. The result of this research showed that one of three atmospheric variables influenced joy that was design, two other variables, that were ambience and interaction were not influence joy and joy influenced the customer loyalty.
\end{abstract}

Keywords: Atmospheric, Joy, Perception, Customer Loyalty

\section{PENDAHULUAN}

Pariwisata merupakan salah satu sumber devisa negara yang sangat potensial dan mempunyai andil cukup besar dalam membangun perekonomian Indonesia. Pengembangan sektor pariwisata yang dilakukan dengan baik akan mampu menarik wisatawan domestik ataupun wisatawan asing untuk datang dan melakukan transaksi selama berwisata. Hal tersebut akan memberikan dampak bagi peningkatan pendapatan masyarakat di sekitar daerah wisata serta menjadi penerimaan devisa bagi negara Indonesia.

Pada tahun 2012, sektor pariwisata diperkirakan menyumbang devisa negara sebesar 9,07 miliar dolar AS atau naik 6,7\% dibandingkan tahun lalu (Sektor Pariwisata Sumbangkan Devisa Negara 9,07 Miliar Dollar, 2012). Penerimaan devisa negara dari sektor pariwisata telah menjadikan pariwisata sebagai sektor kegiatan yang berorientasi ekspor terbesar kelima se- telah minyak gas, minyak kelapa sawit, batu bara dan karet olahan.

Pariwisata merupakan sektor ekonomi yang menekankan pada layanan hedonik yang dapat mendorong emosi konsumen (Barsky \& Nash, 2002; Otto \& Ritchie, 1996). Dari semua jenis layanan, maka pariwisata merupakan layanan yang sangat bertumpu pada pemberian experience kepada pelanggan, karena experience merupakan core product dari pariwisata (Yuan \& $\mathrm{Wu}, 2008$ ).

Pada dasarnya, ada dua wilayah yang telah diteliti dalam konteks experience dalam layanan, yaitu pendekatan experience dari sisi kognitif dan pendekatan emosional, terutama dalam menilai efek dari experience tersebut terhadap variabel lain (Martin et al., 2008). Pendekatan kognitif dianggap kurang tepat untuk menjelaskan dampak experience pada kepuasan pelanggan (Bagozzi, 1997). Pendekatan emosional lebih disarankan sebagai alternatif peng- 
ganti pendekatan kognitif. Riset dengan pendekatan emosional untuk menjelaskan dampak terhadap kepuasan pelanggan dan niat berperilaku sangat kurang, oleh sebab itu penelitian ini mencoba berkontribusi dengan menggunakan pendekatan emosional untuk menjelaskan dampak dari experience (Bigne' et al., 2005).

Penelitian lain, dalam konteks layanan, lebih banyak dilakukan di bidang kualitas layanan (Minor et al., 2004) dan peran karyawan dalam penghantaran jasa (Groönroos, 2001), sedangkan peran aspek lain dalam melahirkan experience jarang diteliti. Padahal ada kemungkinan experience konsumen dibentuk dari atmosfir yang ada di tempat layanan. Heide \& Grønhaug (2006) dalam Slatten et al. (2009) menyarankan perlunya penelitian tentang bagaimana konstruk atmospheric mempengaruhi experience konsumen.

Trans Studio Bandung adalah salah satu bentuk wisata buatan di Indonesia berupa taman bermain dalam ruangan terbesar di dunia yang dikelola oleh Trans Corp. Trans Studio Bandung adalah taman bermain di dalam ruangan kedua yang dibangun untuk menyusul kesuksesan Trans Studio Makassar yang dibangun pada tahun tahun 2009. Taman wisata ini terdiri dari dua lantai dan memiliki 20 wahana permainan yang fantastis. Trans Studio Bandung menciptakan atmospheric melalui komunikasi visual, pencahayaan, warna dan musik, yaitu dengan membagi wilayah menjadi tiga zona kawasan dengan konsep yang berbeda dari sisi desain maupun pencahayaan. Tiga zona yang ada di Trans Studio Bandung adalah Studio Central, The Lost City dan Magic Corner.

Penelitian ini bertujuan untuk mengetahui, menganalisis dan membuktikan besarnya pengaruh atmospheric terhadap loyalty melalui joy pada pengunjung Trans Studio Bandung. Diharapkan hasil penelitian ini dapat memberikan manfaat bagi manajemen Trans Studio Bandung ataupun untuk penelitian selanjutnya.

\section{LANDASAN TEORI DAN HIPOTESIS}

\section{Atmospheric}

Menurut Levy \& Weitz (2004), "Atmospheric refers to the Design of an environment via visual communication, lighting, colors, music, and scent to stimulate customer's perceptual and emotional responses and ultimately to affect their behavior." Definisi di atas mengartikan atmospheric sebagai menciptakan suasana melalui komunikasi visual, pencahayaan, warna, musik dan aroma untuk merangsang persepsi dan respon emosional yang ber- pengaruh terhadap perilaku pelanggan. Atmospheric dapat menjadi kelebihan dari suatu badan usaha, karena keunikan atmospheric yang tercipta menjadikan badan usaha tersebut berbeda dengan badan usaha lain.

Bitner (1992) dalam Slatten et al. (2009) menyatakan bahwa atmospheric sangat penting untuk organisasi yang bergerak di bidang layanan karena jasa diproduksi dan dikonsumsi secara bersamaan. Selain itu, atmospheric juga menentukan bagaimana sebuah badan usaha memberikan pelayanan kepada pelanggan. Oleh sebab itu, atmospheric harus dirancang dan disusun sekreatif mungkin untuk menarik pelanggan. Menurut Heide \& Grønhaug (2006) dalam Slatten et al. (2009), atmospheric dibagi menjadi tiga aspek, yaitu: ambience, interaction dan design.

Ambience didefiniskan sebagai "Ambience relates to customers' perceptions and experiences of the background conditions in the environment," artinya suasana berkaitan erat dengan persepsi pelanggan dan pengalaman pelanggan akan kondisi latar belakang lingkungan tersebut. Kondisi latar belakang yang dimaksudkan meliputi beberapa elemen seperti suara (sound), pencahayaan (light) dan aroma (scent) (Milliman, 1986 dalam Slatten et al., 2009).

Berfokus tentang bagaimana sound menjadi elemen yang penting dari penciptaan suasana, Smith \& Curnow (1966) dalam Slatten et al. (2009) menyatakan "Shoppers spend less time in a store when music is played loudly than when it is played softly." Musik berpengaruh pada waktu yang dihabiskan seseorang di dalam toko. Musik yang berbeda akan memberikan efek yang berbeda pula pada atmospheric yang dirasakan oleh pelanggan dan berkaitan erat dengan perilaku ataupun pengalaman yang dirasakan oleh pelanggan.

Wilson (2003) dalam Slatten et al. (2009) mengemukakan "Different types of music have different effects on the perceived atmosphere." Definisi tersebut menunjukkan tipe musik yang berbeda memiliki pengaruh yang berbeda terhadap atmosfir yang dirasakan. Artinya, dalam upaya meningkatkan atmospheric yang dirasakan oleh konsumen, pemilihan jenis musik yang tepat menjadi pertimbangan yang penting. Penelitian yang mendukung adalah dari Milliman (1986) dalam Slatten et al. (2009), yang menyatakan bahwa tempo yang berbeda dari musik yang dimainkan di restoran berpengaruh terhadap jumlah nota yang diterima oleh kasir.

Lighting adalah faktor penting lainnya dalam membentuk atmospheric. Intensitas cahaya, warna, tipe dan penempatan adalah hal penting untuk mengembangkan atmospheric menjadi menyenangkan. Menurut Heide \& Grønhaug (2006) dalam Slatten et 
al. (2009) pencahayaan yang terang akan membentuk atmospheric yang hidup, sedangkan pencahayaan yang lebih redup akan memberikan ketenangan. Pencahayaan yang tepat dapat menambahkan keindahan dari tekstur bangunan dan memberikan kesan yang baik dari tempat tersebut. Selain itu, atmospheric yang baik memberikan relaksasi bagi pelanggan dan berkaitan erat dengan pengalaman yang dirasakan oleh pelanggan.

Scent, menurut Morrin \& Ratneshwar (2000) dalam Slatten et al. (2009) adalah "Scent that is not emanating from a particular object but is present in the environment" yang berarti aroma tidak berasal dari suatu obyek tertentu, tetapi hadir di dalam lingkungan. Aroma dapat mempengaruhi evaluasi pelanggan akan suatu tempat, karena aroma berkaitan dengan lingkungan tersebut. Hipotesis yang dapat dirumuskan adalah:

$\boldsymbol{H}_{\boldsymbol{l}}$ : Ambience berpengaruh positif terhadap joy pada pengunjung Trans Studio Bandung.

Interaction merupakan interaksi karyawan perusahaan dengan pelanggan. Berdasarkan tipenya, interaksi dibedakan menjadi tiga yaitu, (1) self service (pelanggan saja), (2) layanan interpersonal (pelanggan dan karyawan) dan (3) layanan remote (karyawan saja). Bitner (1992) dalam Slatten et al. (2009) menyatakan bahwa faktor-faktor sosial memberikan pengaruh bagi persepsi pelanggan akan atmospheric suatu tempat tertentu. Tingkatan interaksi yang berbeda akan memberikan persepsi yang berbeda pula terhadap persepsi pelanggan pada saat mengunjungi suatu tempat tertentu. Interaksi yang minim dapat memberikan kesan asing atas suatu tempat yang tertentu, sedangkan interaksi yang tepat kepada pelanggan akan memberikan persepsi yang baik bahwa tempat tersebut sangat bersahabat. Perusahaan harus memberikan pelayanan yang baik, lebih baik dan memenuhi harapan pelanggan. Sebagai contoh Disney melakukan pelatihan kepada karyawan selama beberapa bulan untuk memberikan pengetahuan tentang cara karyawan berinteraksi dengan pelanggan selama berada di taman bermain.

Kemampuan karyawan untuk memenuhi kebutuhan pelanggan atau dalam menghadapi kegagalan pelayanan sangat berkaitan erat dengan persepsi pelanggan dan pengalaman yang dirasakan selama berada di tempat tersebut. Pelayanan karyawan yang ramah, sangat membantu dan selalu tersedia untuk membantu pelanggan dapat memberikan kesenangan bagi pelanggan. Senyum sederhana dari seorang karyawan dapat dengan sendirinya menghasilkan tingkat kepuasan pelanggan yang lebih tinggi (So- derlund \& Rosengren, 2008 dalam Slatten et al., 2009).

Menurut Oliver (1993) “... satisfaction is all salient dimensions, requires experience dependency and involves emotions." Kepuasan adalah dimensi yang penting, membutuhkan pengalaman dan keterlibatan emosi. Sebagai contoh interaksi antara pemandu dan pelanggan di area rafting memberikan keterlibatan emosi yang pada akhirnya akan menghasilkan sebuah kepuasan dari pelanggan.

Menurut penelitian dari Arnould and Price's (1993) dalam Slatten et al. (2009) interaksi antara pemandu (karyawan) dan pelanggan pada saat rafting terhubung dengan emosi pelanggan, baik emosi positif maupun emosi negatif. Karyawan harus menekankan pada penciptaan pengalaman yang menyenangkan dan menghibur selama interaksi akan mempengaruhi perasaan positif dari pelanggan seperti sukacita.

Badan usaha harus berjuang untuk menyampaikan layanan dengan baik sesuai dengan ekspetasi atau lebih daripada ekspetasi pelanggan. Penyampaian layanan dari penyedia jasa kepada pelanggan dapat dilakukan melalui interaksi antara penyedia jasa dan pelanggan. Menurut Bitner (1990) dalam Slatten et al., (2009) kemampuan karyawan untuk merespon kebutuhan pelangan atau tindakan karyawan tanpa diminta berhubungan langsung dengan persepsi pelanggan terhadap karyawan badan usaha tersebut. Semakin tinggi kontak dengan pelanggan maka semakin tinggi peluang penjualan (Chase, 1981 dalam Slatten et al., 2009).

Badan usaha sebagai penyedia layanan memiliki tujuan untuk memberikan pengalaman yang menyenangkan kepada pelanggan ketika pelanggan menggunakan pelayanan yang disediakan. Adelmann \& Zanonc (1989), Lundqvist \& Dimberg (1995) dalam Slatten et al. (2009) mengemukakan adanya hubungan antara wajah dan suara yang bahagia dari penyedia layanan terhadap perasaan sukacita pengunjung. Hipotesis yang dapat dirumuskan adalah:

$\boldsymbol{H}_{2}$ : Interaction berpengaruh positif terhadap Joy pada pengunjung Trans Studio Bandung

Design adalah hal yang berhubungan dengan lingkungan fisik (Bitner, 1992 dalam Slatten et al., 2009). Seperti ambience, design dapat dirasakan melalui panca indera, hanya saja design lebih berfokus kepada benda-benda yang terlihat oleh mata dan interaksi secara langsung yang dilakukan oleh pelanggan. Design sebuah tempat memiliki beberapa manfaat untuk menciptakan sebuah pengaruh kepada pelanggan. Kotler (1973) menyatakan "... the conscious design of space to create certain effect in buyers." 
Ruangan yang didesain untuk menciptakan pengaruh tertentu kepada pelanggan. Design mampu menimbulkan ketertarikan dari pelanggan untuk datang ke sebuah tempat tertentu. Sebagai contoh Hard Rock Cafe, memberikan design yang berkonsep rock and roll dengan gitar yang ditandai oleh John Lennon atau jaket kulit dari Elvis Presley. Contoh tersebut menunjukkan design berpengaruh pada pengalaman pelanggan. Design dapat memberikan pengaruh kepada pelanggan untuk mengingat kembali tempat tersebut, merekomendasikan, datang kembali atau meninggalkan tempat tersebut dan tidak akan pernah kembali lagi.

Secara khusus, design merupakan faktor yang sangat penting untuk badan usaha yang menyediakan pelayanan jasa seperti winter park (Slatten et al., 2009). Badan usaha harus dapat menyediakan design yang berpengaruh terhadap pengalaman mereka, karena tujuan utama pengunjung adalah untuk mendapatkan pengalaman yang menarik dan menyenangkan.

Pine \& Gilmore (1998) dalam Slatten et al. (2009) menyatakan "An effecttive physical design is concise, compelling and engaging to all senses." Artinya desain fisik yang efektif adalah desain yang ringkas, menarik dan mengikat semua perasaan. Design yang efektif akan dapat mengikat perasaan seseorang yang melihatnya. Design harus dikelola dengan baik karena dapat mempengaruhi emosi seseorang, baik emosi positif maupun emosi negatif.

Penelitian sebelumnya mengemukakan design dapat membangkitkan perasaan emosional seseorang. Sejalan dengan penelitian tersebut, Wasserman et al. (2000) dalam Slatten et al. (2009) mengemukakan "Contend that different restaurant layout and interior design influenced cutomer' emotion." Artinya tata letak dan desain interior yang berbeda dari sebuah restoran dapat berpengaruh terhadap emosi pelanggan. Setiap design yang sengaja diciptakan oleh badan usaha dapat menimbulkan emosi yang berbeda. Sebagai contoh Walt Disney yang dikenal dengan design berkonsep fantasy pada bangunannya dan Sea World yang dikenal dengan design di dalam laut dapat menimbulkan emosi yang berbeda. Berdasarkan argumentasi tersebut, hipotesis yang dapat dirumuskan adalah:

$\boldsymbol{H}_{3}$ : Design berpengaruh positif terhadap Joy pada pengunjung Trans Studio Bandung

\section{Joy}

Emosi dapat dihasilkan dari pengalaman pelanggan dan emosi berhubungan langsung dengan perilaku pasca pembelian serta perilaku perencanaan pembelian kembali (Westbrook, 1987 dalam Slatten et al.,
2009). Menurut Bagozzi (1997) dalam Slatten et al. (2009), "Emotions perform different functions and operate at different levels under various stages of customer decision making," yang berarti emosi melakukan fungsi yang berbeda dan beroperasi pada tingkat yang berbeda tergantung pada tahapan pengambilan keputusan pelanggan.

Secara umum, emosi dibagi menjadi dua kelompok yaitu positif dan negatif (Bagozzi et al., 1999 dalam Slatten et al., 2009). Menurut Wright et al. (2007) dalam Slatten et al. (2009), joy adalah emosi yang sangat positif. Adler et al. (2003) menyatakan bahwa joyful atau kebahagiaan berarti feelling good, having fun, having a good time, atau sesuatu yang membuat pengalaman yang menyenangkan.

Hubungan positif antara perasaan dan loyalitas dapat dilihat dari perilaku seseorang. Hal ini berkaitan dengan kebiasaan manusia pada saat merespon perasaan positif yaitu dengan menghindari perasaan negatif seperti yang dikemukakan oleh Slatten et al. (2009). Secara spesifik, perasaan positif seseorang terhubung dengan keputusan pelanggan untuk tinggal atau pergi, serta keputusan pelanggan untuk melanjutkan apa yang mereka lakukan atau menghentikannya.

Penelitian sebelumnya membuktikan bahwa adanya hubungan antara emosi dan loyalitas. Strauss \& Neuhaus (1997) mengemukakan adanya hubungan yang positif antara emosi dan perilaku. Sejalan dengan penelitian tersebut, Allen et al. (1992) dalam Slatten et al. (2009) menujukkan pengalaman yang efektif dapat dijadikan landasan untuk memprediksi perilaku pembelian. Oleh karena itu, badan usaha harus terus berusaha menciptakan emosi yang positif dari pelanggan, karena emosi yang positif berkaitan dengan perilaku pelanggan. Berdasarkan argumentasi tersebut, dapat dirumuskan hipotesis sebagai berikut:

\section{$\boldsymbol{H}_{4}$ : Joy berpengaruh positif terhadap customer} loyalty pada pengunjung Trans Studio Bandung

\section{Customer Loyalty}

Menurut Griffin (1995), konsep dari loyalitas pelanggan digerakkan oleh perilaku daripada sikap. Pelanggan dikatakan loyal apabila pelanggan memiliki sikap pembelian secara teratur. Selain itu, loyalitas mengandung arti kondisi yang melakukan pembelian tidak kurang daripada dua kali atau menggunakan jasa secara terus menerus. Menurut Zeithaml et al. (1996) dalam Slatten et al. (2009) ukuran loyalitas adalah memberikan rekomendasi kepada orang lain dan pujian, sehingga loyalitas pelanggan dapat juga tunjukkan dengan sikap memberitakan hal-hal yang positif akan produk atau jasa tertentu kepada 
orang lain dan mempengaruhi orang lain untuk menggunakan produk dan jasa yang sama.

\section{METODE PENELITIAN}

Variabel eksogen (exogenous variable) yang digunakan dalam penelitian ini adalah atmospheric. Atmospheric adalah suasana yang tercipta melalui komunikasi visual, pencahayaan, warna, musik, dan aroma untuk merangsang persepsi dan respon emosional yang berpengaruh terhadap perilaku pelanggan. Pada penelitian ini indikator yang digunakan untuk mengukur atmospheric, yaitu:

(1) Ambience adalah suasana yang tercipta dari Trans Studio Bandung dan dapat dirasakan oleh pengunjung. Pengukuran terhadap Ambience pada Trans Studio Bandung ini dilakukan melalui indikator yang terdiri dari: (a) Aroma yang tercium di Trans Studio Bandung, (b) Pencahayaan Trans Studio Bandung dan (c) Suara yang terdengar di Trans Studio Bandung.

(2) Interaction adalah interaksi yang terjadi antara pengunjung dan karyawan Trans Studio Bandung. Interaksi tersebut dapat berupa pemberian informasi dari karyawan kepada pengunjung, sehingga pengunjung merasa terbantu dengan adanya informasi-informasi yang di berikan oleh karyawan. Interaction diukur dengan indikator pengukuran sebagai berikut: (a) Pengetahuan karyawan mengenai Trans Studio Bandung, (b) Keramahan karyawan Trans Studio Bandung dalam melayani, (c) Kesigapan dari karyawan Trans Studio Bandung membantu pengunjung dan (d) Trans Studio Bandung memiliki jumlah karyawan yang cukup.

(3) Design adalah semua hal yang berhubungan dengan lingkungan fisik Trans Studio Bandung. Desain berfokus kepada bendabenda yang terlihat oleh mata. Pengukuran terhadap design diukur dengan indikator pengukuran sebagai berikut: (a) Kesesuaian dekorasi fisik yang tampak dengan konsep yang terdapat di Trans Studio Bandungn dan (b) Kesesuaian arsitektur bangunan dengan konsep yang terdapat di Trans Studio Bandung.

Variabel Endogen (endogenous variable) yang digunakan dalam penelitian ini adalah joy dan customer loyalty. Pada penelitian ini indikator yang digunakan untuk mengukur joy dan customer loyalty yaitu:

(1) Joy adalah suatu perasaan positif yang dirasakan oleh seseorang setelah mengalami pengalaman atau kejadian tertentu. Pengukuran terhadap Joy pada pengunjung Trans Studio Bandung dilakukan dengan melalui indikator Trans Studio
Bandung yang terdiri dari: (a) Perasaan bahagia selama berkunjung di Trans Studio Bandung dan (b) Perasaan bersemangat selama berkunjung di Trans Studio Bandung

(2) Customer Loyalty adalah komitmen yang kuat dari pelanggan untuk berlangganan kembali atau melakukan pembelian ulang produk atau jasa yang disukai secara konsisten di masa yang akan datang, meskipun pengaruh situasi dan usahausaha pemasaran mempunyai potensi untuk menimbulkan perilaku untuk berpindah. Pengukuran terhadap Customer Loyalty pada pengunjung Trans Studio Bandung dilakukan dengan melalui indikator Trans Studio Bandung yang terdiri dari: (a) Keinginan untuk merekomendasikan Trans Studio Bandung kepada orang lain (b) Keinginan untuk mengatakan hal positif mengenai Trans Studio Bandung.

Sumber data yang digunakan adalah data primer. Data ini diperoleh melalui pembagian kuesioner kepada para pengunjung Trans Studio Bandung. Aras pengukuran yang digunakan dalam penelitian ini adalah aras interval. Aras interval adalah aras pengukuran yang memiliki jarak yang sama dan selisih yang jelas pada skala. Alternatif jawaban yang disediakan untuk aras interval disusun berdasarkan numerical scale yang dilakukan dengan memberikan penilaian kepada serangkaian pernyataan berdasarkan kata sifat yang diukur dalam tujuh skala jenjang, seperti:

Sangat tidak setuju 12234567 Sangat Setuju

Angka satu menunjukkan bahwa responden sangat tidak setuju dengan atmospheric yang diberikan Trans Studio Bandung dan semakin mendekati angka tujuh, maka semakin setuju dengan atmospheric yang diberikan Trans Studio Bandung.

Target populasi dalam penelitian ini adalah pelanggan yang sedang berkunjung ke Trans Studio Bandung. Karakteristik yang ditetapkan adalah pengunjung yang telah mengunjungi Trans Studio Bandung minimal satu kali dalam tiga bulan terakhir dan telah mengunjungi semua zona di Trans Studio Bandung. Dalam penelitian ini, pelanggan populasi tidak teridentifikasi secara jelas, maka jenis pengambilan sampel yang dipilih adalah dengan menggunakan teknik nonprobability sampling yaitu convenience sampling, yaitu teknik pengambilan sampel yang mengambil elemen-elemen yang termudah saja.

Pengumpulan data dilakukan dengan membagikan kuesioner di lokasi Trans Studio Bandung selama tiga hari. Hasil kuesioner kemudian dipilah lagi untuk memastikan kesesuaian target karakteristik yang di- 
inginkan. Hasil kuesioner ini kemudian di input ke dalam software pengolah statistik untuk proses uji validitas dan reliabilitas. Setelah itu proses pengerjaan structural equation model dapat dilakukan.

Pengolahan data dalam penelitian ini menggunakan Structural Equation Modeling (SEM) dengan menggunakan software LISREL 8.70. Pendekatan yang digunakan adalah pendekatan dua tahap dengan model pengukuran dan struktural. Oleh karena itu, ukuran sampel yang digunakan dalam penelitian harus sesuai dengan persyaratan dalam metode tersebut. Jumlah sampel yang diambil dalam penelitian ini adalah sebanyak 120 responden karena menurut Hair, et al. (1998) dalam Ferdinand (2002) ukuran sampel adalah minimum 100 sedangkan maksimal tidak lebih dari 400. Sampel dalam penelitian ini adalah 120 .

\section{HASIL PENELITIAN DAN PEMBAHASAN}

Dari keseluruhan hasil uji validitas dan reliabilitas menunjukkan bahwa kuesioner yang telah dirancang untuk menguji hipotesis kerja dalam penelitian ini telah memenuhi syarat validitas dan reliabilitas, sehingga kuesioner tahap kedua dapat digunakan untuk mendapatkan jumlah sampel yang telah ditetapkan. Setelah kuesioner dinyatakan valid dan reliabel, maka penyebaran dianjutkan untuk mendapatkan 120 sampel. Kuesioner tahap kedua dibagikan sebanyak 113 kuesioner karena 23 kuesioner tidak memenuhi karakteristik.

Dari 120 orang yang menjadi responden dalam penelitian ini, diketahui bahwa responden yang berjenis kelamin pria sebesar 39,2\% dan berjenis kelamin wanita sebesar $60,8 \%$. Dari sisi usia $57,5 \%$ memiliki usia 18-20 tahun, 30\% memiliki usia 21-25 tahun, $10 \%$ memiliki usia 26-30 tahun dan 2,5\% memiliki usia 31-35 tahun.

Tabel 1 menunjukkan rata-rata untuk variabel ambience sebesar 5,5133. Pernyataan ambience mendapat penilaian terendah dari tiga item adalah A2 dengan nilai rata-rata 5,40. Pernyatan A1 mendapat penilaian tertinggi dengan rata-rata 5,67.

Tabel 2 menunjukkan rata-rata untuk variabel interaction sebesar 5,67. Pernyataan interaction mendapat penilaian terendah dari empat item adalah I4 dengan nilai rata-rata 5,64, sedangkan pernyataan I1 mendapat penilaian tertinggi dengan rata-rata 5,70.

Tabel 3 menunjukkan rata-rata untuk variabel design sebesar 5,315. Pernyataan design mendapat penilaian terendah dari dua item adalah $\mathrm{D} 2$ dengan nilai rata-rata 5,31, sedangkan pernyataan D1 mendapat penilaian tertinggi dengan rata-rata 5,32.

Tabel 4 menunjukkan rata-rata untuk variabel joy sebesar 5,265. Pernyataan joy mendapat penilaian terendah dari dua item adalah $\mathrm{J} 2$ dengan nilai rata-rata 5,24 , sedangkan pernyataan $\mathrm{J} 1$ mendapat penilaian tertinggi dengan rata-rata 5,29.

Tabel 1. Rekapitulasi Jawaban Responden Variabel Ambience

\begin{tabular}{clcc}
\hline $\begin{array}{l}\text { Indi-- } \\
\text { kator }\end{array}$ & Pernyataan & St.dev \\
\hline $\mathrm{A}_{1}$ & $\begin{array}{l}\text { Bebauan yang tercium di dalam } \\
\text { Trans Studio Bandung berperan } \\
\text { terhadap pengalaman saya selama } \\
\text { berkunjung di Trans Studio Ban- }\end{array}$ & 5,67 & 1,205 \\
& & \\
$\mathrm{~A}_{2}$ & $\begin{array}{l}\text { dung } \\
\text { Pencahayaan di dalam Trans } \\
\text { Studio Bandung berperan ter- } \\
\text { hadap pengalaman saya selama } \\
\text { berkunjung di Trans Studio Ban- } \\
\text { dung }\end{array}$ & 5,40 & 1,177 \\
$\mathrm{~A}_{3} \quad \begin{array}{l}\text { Suara yang terdengar di dalam } \\
\text { Trans Studio Bandung berperan } \\
\text { terhadap pengalaman saya selama } \\
\text { berkunjung di Trans Studio Ban- } \\
\text { dung }\end{array}$ & 5,47 & 1,100 \\
\hline Total & & \\
\hline
\end{tabular}

Tabel 2. Rekapitulasi Jawaban Responden Variabel Interaction

\begin{tabular}{|c|c|c|c|}
\hline $\begin{array}{l}\text { Indi- } \\
\text { kator }\end{array}$ & Pernyataan & Mean & St.dev \\
\hline $\mathrm{I}_{1}$ & $\begin{array}{l}\text { Menurut saya, staff di Trans Stu- } \\
\text { dio Bandung berpengetahuan luas } \\
\text { mengenai Trans Studio Bandung }\end{array}$ & 5,70 & 1.089 \\
\hline $\mathrm{I}_{2}$ & $\begin{array}{l}\text { Menurut saya, staff di Trans Stu- } \\
\text { dio Bandung ramah dalam mela- } \\
\text { yani }\end{array}$ & 5,68 & 1,012 \\
\hline $\mathrm{I}_{3}$ & $\begin{array}{l}\text { Menurut saya, staff di Trans Stu- } \\
\text { dio Bandung sigap dalam mem- } \\
\text { bantu pengunjung }\end{array}$ & 5,66 & 0,946 \\
\hline $\mathrm{I}_{4}$ & $\begin{array}{l}\text { Menurut saya, Trans Studio mem- } \\
\text { iliki jumlah staff yang cukup }\end{array}$ & 5,64 & 1,019 \\
\hline \multicolumn{2}{|c|}{ Total Mean dan St. dev } & 5,67 & 1,016 \\
\hline
\end{tabular}

Tabel 3. Rekapitulasi Jawaban Responden Variabel Design

\begin{tabular}{clcc}
\hline $\begin{array}{c}\text { Indi- } \\
\text { kator }\end{array}$ & \multicolumn{1}{c}{ Pernyataan } & Mean & St.dev \\
\hline $\mathrm{D}_{1}$ & $\begin{array}{l}\text { Kesesuaian dekorasi fisik di } \\
\text { Trans Studio Bandung berperan } \\
\text { terhadap pengalaman saya selama } \\
\text { berkunjung di Trans Studio Ban- } \\
\text { dung }\end{array}$ & 5,32 & 1,159 \\
$\mathrm{D}_{2}$ & $\begin{array}{l}\text { Kesesuaian arsitektur bangunan } \\
\text { yang terlihat di Trans Studio } \\
\text { Bandung berperan terhadap pen- } \\
\text { galaman saya selama berkunjung } \\
\text { di Trans Studio Bandung }\end{array}$ & 5,31 & 1,083 \\
\hline & & \\
\hline
\end{tabular}


Tabel 5 menunjukkan rata-rata untuk variabel customer loyalty sebesar 5.525. Pernyataan customer loyalty mendapat penilaian terendah dari dua item adalah L2 dengan nilai rata-rata 5,52, sedangkan pernyataan L1 mendapat penilaian tertinggi dengan rata-rata 5,53

Structural Equation Modeling dalam penelitian ini menggunakan pendekatan dua tahap, yaitu model pengukuran dan model struktural. Hasil kecocokan model pengukuran dapat dilihat di Tabel 6 .

Tabel 4. Rekapitulasi Jawaban Responden Variabel Joy

\begin{tabular}{|c|c|c|c|}
\hline $\begin{array}{l}\text { Indi- } \\
\text { kator }\end{array}$ & Pernyataan & Mean & St.dev \\
\hline $\mathrm{J}_{1}$ & $\begin{array}{l}\text { Saya merasa bahagia selama } \\
\text { kunjungan saya di Trans } \\
\text { Studio Bandung }\end{array}$ & 5,29 & 1,219 \\
\hline $\mathrm{J}_{2}$ & $\begin{array}{l}\text { Saya merasa bersemangat } \\
\text { selama kunjungan saya di } \\
\text { Trans Studio Bandung }\end{array}$ & 5,24 & 1,108 \\
\hline & Total Mean dan St. dev & 5,265 & 1,1635 \\
\hline
\end{tabular}

Tabel 5. Rekapitulasi Jawaban Responden Variabel Customer Loyalty

\begin{tabular}{cccc}
\hline $\begin{array}{c}\text { Indi- } \\
\text { kator }\end{array}$ & Pernyataan & Mean & St.dev \\
\hline $\mathrm{L}_{1}$ & $\begin{array}{l}\text { Saya akan merekomendasikan } \\
\text { Trans Studio Bandung kepada } \\
\text { orang lain }\end{array}$ & 5,53 & 0,925 \\
$\mathrm{~L}_{2}$ & $\begin{array}{l}\text { Saya akan mengatakan hal-hal } \\
\text { positif mengenai Trans Studio } \\
\text { Bandung kepada orang lain }\end{array}$ & 5,52 & 1,029 \\
\hline Total Mean dan St. dev & 5,525 & 1,954 \\
\hline
\end{tabular}

Dapat dilihat dari Tabel 7 bahwa model pengukuran ini dapat dikatakan telah fit. Nilai RMSEA dari hasi uji kecocokan juga dapat dikatakan baik karena $0,034>0,08$. Hal ini berarti tingkat error model apabila diestimasi dalam populasi cukup rendah.

Nilai std. loading (standarized loading) dapat diperoleh secara langsung dari keluaran program LISREL, sedangkan nilai error yang merupakan measurement error untuk setiap indikator juga di- dapatkan dari keluaran program LISREL. Berdasarkan hasil pengujian tersebut, diperoleh nilai costruct reliability pada semua variabel lebih besar dari 0,7 , sehingga variabel yang digunakan secara umum sudah reliabel.

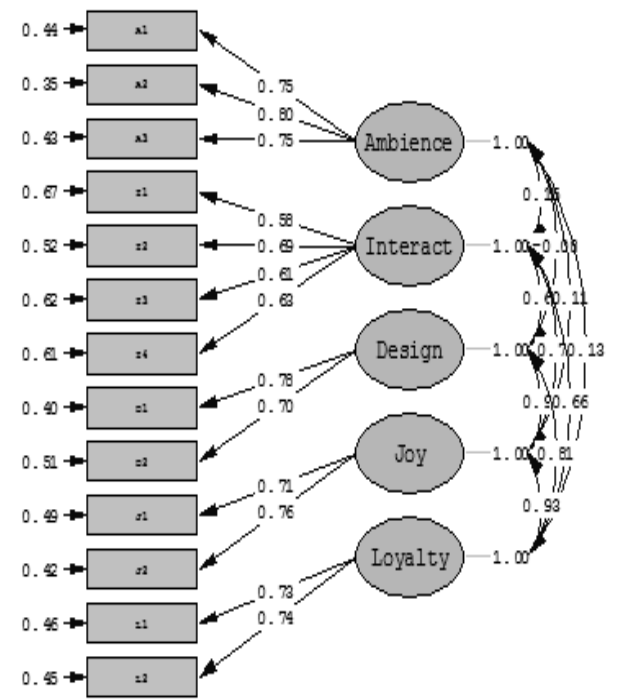

Chi-8quare $=62.45, d f=55, p-v a l u e=0.22861$, RMSEA $=0.034$

Gambar 1. Measurement Model

Tabel 7. Composite Reliablity

\begin{tabular}{|c|c|c|c|c|}
\hline Variabel & 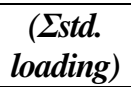 & $\begin{array}{c}(\Sigma s t d . \\
\text { loading })^{2}\end{array}$ & Eerror & $\begin{array}{l}\text { Composite } \\
\text { Reliability }\end{array}$ \\
\hline Ambience & 2,3 & 5,29 & 1,22 & 0,812596006 \\
\hline Interaction & 2,51 & 6,3001 & 2,42 & 0,722480247 \\
\hline Design & 1,48 & 2,1904 & 0,91 & 0,706489485 \\
\hline Joy & 1,47 & 2,1609 & 0,91 & 0,703669934 \\
\hline $\begin{array}{l}\text { Customer } \\
\text { Loyalty }\end{array}$ & 1,47 & 2,1609 & 0,91 & 0,703669934 \\
\hline
\end{tabular}

Argumen untuk menjelaskan variance extracted dari interaction adalah pada penelitian ini, interaksi yang diukur adalah interaksi antara karyawan dan pengunjung, sehingga intensitas dari interaksi daripada karyawan sangat berpengaruh. Minimnya interaksi dapat terjadi karena banyaknya pengunjung Trans Studio Bandung pada saat penelitian dilaksanakan.

Tabel 6. Hasil Uji Kecocokan Model Pengukuran

\begin{tabular}{cccc}
\hline Uji Kecocokan & Kriteria Kecocokan & Hasil & Keterangan \\
\hline Chi-Square Statistic & Berukuran 100 sampai dengan 200, $p>0,05$ & 62,45 & Marginal Fit \\
RMSEA & $R M S E A \leq 0,08$ & $P=0,023$ & \\
GFI & $G F I \geq 0,90$ & 0,034 & Good Fit \\
CMIN/DF & $C M I N / D F \leq 2$ & 0,93 & Good Fit \\
CFI & $C F I \geq 0,90$ & 1,135 & Good Fit \\
TLI/NNFI & $N N F I \geq 090$ & 0,99 & Good Fit \\
\hline
\end{tabular}


Tabel 8. Variance Extracted

\begin{tabular}{|c|c|c|c|c|}
\hline Variabel & $\begin{array}{c}\text { (Estd. } \\
\text { loading) }\end{array}$ & $\begin{array}{c}\Sigma s t d . \\
\text { loading }\end{array}$ & Eerror & $\begin{array}{l}\text { Variance } \\
\text { Extracted }\end{array}$ \\
\hline Ambience & 2,3 & 1,9525 & 1,22 & 0,615445232 \\
\hline Interaction & 2,51 & 1,5815 & 2,42 & 0,395226790 \\
\hline Design & 1,48 & 1,0984 & 0,91 & 0,546903007 \\
\hline Joy & 1,47 & 1,0817 & 0,91 & 0,543103881 \\
\hline $\begin{array}{l}\text { Customer } \\
\text { Loyalty }\end{array}$ & 1,47 & 1,0805 & 0,91 & 0,542828435 \\
\hline
\end{tabular}

Menurut Hatcher dalam Longino (2007) menyatakan "The variance extracted estimate test is conservative, reliabilities can be acceptable even if variance extracted estimates are less than 0,50." Pengujian variance extracted bersifat konservatif, reliabilitas dapat diterima bahkan jika variance extracted kurang dari 0,50 .

Hasil dari evaluasi ini dapat dilihat pada Gambar 4 dan dirangkum pada Tabel 9 ditambah dengan asumsi hipotesis-hipotesis dari model penelitian sebagai berikut:

$\boldsymbol{H}_{1}$ : Ambience berpengaruh positif terhadap Joy pada pengunjung Trans Studio Bandung

$\boldsymbol{H}_{2}$ : Interaction berpengaruh positif terhadap Joy pada pengunjung Trans Studio Bandung

$\boldsymbol{H}_{3}$ : Design berpengaruh positif terhadap Joy pada pengunjung Trans Studio Bandung

$\boldsymbol{H}_{4}$ : Joy berpengaruh positif terhadap Customer Loyalty pada pengunjung Trans Studio Bandung

Uji hipotesis dilakukan dengan melihat nilai $t(t-$ value) untuk setiap koefisien, Nilai $t$-signifikan apabila $\geq 1,96$ yang berarti hipotesis dapat diterima, nilai $t<1,96$ tidak signifikan dan hipotesis ditolak. Uji hipotesis juga dapat dilakukan dengan melihat gambar T-value, pada Gambar 4 dapat dilihat angka di bawah 1,96 berarti tidak signifikan dan hipotesis ditolak.

Berdasarkan uji $t$ pengaruh ambience pada joy diperoleh nilai sebesar 1,73 yang menunjukkan ambience tidak secara signifikan mempengaruhi joy pada pengunjung Trans Studio Bandung. Hal ini menyatakan bahwa hipotesis 1 tidak diterima. Hal ini berlawanan dengan penelitian yang ada yaitu "Ambience relates to customers' perceptions and experiences of the background conditions in the environment" (Milliman, 1986 dalam Slatten et al., 2009). Ambience berkaitan erat dengan persepsi dan pengalaman pelanggan akan kondisi latar belakang lingkungan tersebut. Ambience yang menyenangkan akan menimbulkan sebuah perasaan nyaman dan memberikan pengaruh terhadap suasana hati. Sejalan dengan penelitian tersebut Barsky \& Nash (2002), Otto \& Ritchie (1996), Ryan (1999) dalam Slatten et al. (2009) mengatakan bahwa 'Customer' experien- ces of atmosphere in hedonic services are also able to evoke customer' feelling of joy." Artinya pengalaman pelanggan akan atmosfir dari jasa hedonis dapat membangkitkan perasaan bahagia pelanggan. Atmospheric yang diciptakan melalui ambience berperan positif terhadap perasaan bahagia dari pelanggan.

Argumen yang dapat menjelaskan penelitian ini adalah ambience yang diciptakan oleh Trans Studio Bandung tidak dapat dirasakan secara optimal oleh pengunjung. Letak Trans Studio Bandung yang berada di dalam ruangan menjadikan pencahayaan yang ada terlihat seperti pencahayaan ruangan seperti biasa, dan tata letak lampu lebih terlihat seperti desain ruangan. Selain itu, ambience yang hanya dijelaskan melalui tiga faktor yaitu pencahayaan, suara dan aroma terlalu sedikit untuk menggambarkan ambience (Slatten et al., 2009). Apabila ada satu faktor saja yang kurang dari penciptaan ambience pada Trans Studio Bandung dirasakan kurang efektif karena terlalu sedikit untuk menggambarkan ambience. Satu faktor saja yang tidak dapat dirasakan atau disadari oleh pengunjung akan berpengaruh terhadap kedua faktor lainnya dan dapat menghasilkan hubungan yang tidak signifikan.

Interaction tidak mempengaruhi Joy secara signifikan pada pengunjung Trans Studio Bandung, sehingga hipotesis 2 tidak diterima. Hal ini berlawanan dengan penelitian yang ada yaitu "Previous research links service providers' smilling faces and happy voices to the inducement of joy" (Adelmann \& Zanonc, 1989; Lundqvist \& Dimberg, 1995). Penelitian sebelumnya mengemukakan adanya hubungan antara wajah dan suara yang bahagia dari penyedia jasa memberikan pengaruh terhadap perasaan sukacita pengunjung. Penelitian lain mengemukakan senyum sederhana dari seorang karyawan dapat dengan sendirinya menghasilkan tingkat kepuasan pelanggan yang lebih tinggi (Søderlund \& Rosengren, 2008).

Argumen yang dapat menjelaskan hal ini adalah faktor yang digunakan untuk mengukur pengaruh interaksi terhadap kebahagiaan hanya sebatas interaksi antara karyawan dan pengunjung. Interaksi antara karyawan dan pengunjung digambarkan melalui pengetahuan, kesigapan dan ketersediaan dari staff Trans Studio Bandung. Selain interaksi antara karyawan dengan pengunjung masih ada bentuk interaksi lain, yaitu interaksi antar pengunjung (Grove \& Fisk, 1997). Interaksi ini tidak diukur dalam penelitian ini, sehingga mungkin menghasilkan hubungan yang tidak signifikan.

Design secara signifikan mempengaruhi joy pada pengunjung Trans Studio Bandung. Hal ini sejalan 
dengan penelitian yang ada, yaitu Mehrabian and Russell (1974) dalam Slatten et al. (2009) menyimpulkan bahwa desain mendorong seseorang untuk tetap tinggal atau meninggalkan suatu tempat tertentu. Sejalan dengan penelitian di atas, Wasserman et al. (2000) dalam Slatten et al. (2009) mengemukakan bahwa desain interior dan tata letak yang berbeda dapat mempengaruhi perasaan emosional pelanggan.

Desain yang ada di Trans Studio Bandung mampu menggambarkan setiap konsep dari zona yang ada di Trans Studio Bandung. Desain yang ada di Trans Studio Bandung terbagi menjadi tiga konsep dan didukung dengan arsitektur serta ornamen fisik yang sesuai dengan konsep dari setiap zona yang ada.

Joy secara signifikan mempengaruhi customer loyalty pada pengunjung Trans Studio Bandung. Hal ini sejalan dengan penelitian sebelumnya yang membuktikan adanya hubungan antara emosi dan loyalitas pelanggan. Westbrook (1987) dalam Slatten et al. (2009) menyatakan bahwa emosi dihasilkan dari pengalaman pelanggan dan berpengaruh secara langsung terhadap perilaku pasca pembelian seperti rencana pembelian kembali. Sejalan dengan penelitian yang dilakukan oleh beberapa peneliti seperti Westbrook (1987) dan Neuhaus (1997) dalam Slatten et al. (2009) melaporkan adanya hubungan yang signifikan antara emosi dan loyalitas.

\section{SIMPULAN DAN SARAN}

Berdasarkan hasil penelitan dan pengujian secara statistik yang dilakukan, maka dapat diperoleh kesimpulan bahwa dari empat hipotesis yang dikembangkan terdapat dua yang terbukti dan dua yang tidak terbukti. Berikut ini adalah penjelasannya secara spesifik:

a. Terdapat pengaruh secara tidak signifikan ambience terhadap joy pada pengunjung Trans Studio Bandung.

b. Terdapat pengaruh secara tidak signifikan interaction terhadap joy pada pengunjung Trans Studio Bandung.

c. Terdapat pengaruh secara signifikan design terhadap joy pada pengunjung Trans Studio Bandung.

d. Terdapat pengaruh secara signifikan joy terhadap customer loyalty pada pengunjung Trans Studio Bandung.

Meskipun dalam penelitian ini hanya dua hipotesis yang terbukti, namun model yang ada telah menggambarkan hasil data yang ada di lapangan. Hal ini terbukti dari pengujian goodness of fit yang menunjukkan kesesuaian model terhadap data dapat dikatakan baik.
Penelitian ini membawa implikasi bagi pengembangan teori yang menjelaskan tentang peran atmospheric dalam pembentukan experience konsumen. Berdasarkan hasil penelitian ini, ambience tidak secara signifikan berpengaruh terhadap joy. Hal ini berbeda dengan penelitian Milliman (1986) dalam Slatten et al. (2009) yaitu ambience relates to customers' perceptions and experiences of the background conditions in the environment yang artinya ambience berkaitan erat dengan persepsi dan pengalaman pelanggan akan kondisi latar belakang lingkungan tersebut. Ambience yang baik akan menghasilkan persepsi serta pengalaman yang menyenangkan dan dapat membangkitkan perasaan bahagia.

Hasil penelitian ini menunjukkan bahwa interaction tidak secara signifikan berpengaruh terhadap joy. Hal ini berlawanan dengan penelitian (Adelmann \& Zanonc, 1989; Lundqvist \& Dimberg, 1995) dalam yaitu service providers' smilling faces and happy voices to the inducement of joy. Artinya adanya hubungan antara wajah dan suara yang bahagia dari penyedia jasa dengan perasaan sukacita. Apabila penyedia layanan jasa memiliki pelayanan yang positif dan menyenangkan maka perasaan pengunjung akan positif dan menyenangkan juga.

Penelitian ini menunjukkan bahwa design berpengaruh terhadap joy. Hal ini didukung oleh penelitian Wasserman et al. (2000) dalam Slatten et al. (2009) yang mengemukakan bahwa desain interior dan tata letak yang berbeda dapat mempengaruhi perasaan emosional dari pelanggan. Emosional pelanggan yang dimaksud dalam penelitian ini adalah joy. Design merupakan faktor penting untuk membangkitkan kebahagiaan dari pengunjung, karena desain yang tepat akan memberikan pengaruh positif kepada perasaan emosional pengunjung.

Hasil penelitian menunjukkan bahwa joy berpengaruh positif terhadap costumer loyalty. Hal ini sejalan dengan penelitian dari Westbrook (1987) dalam Slatten et al. (2009) yang menyatakan bahwa emosi dihasilkan dari pengalaman pelanggan dan berpengaruh secara langsung terhadap perilaku pasca pembelian seperti rencana pembelian kembali. Sejalan dengan penelitian yang dilakukan oleh beberapa peneliti seperti Westbrook (1987) dan Neuhaus (1997) dalam Slatten et al. (2009) melaporkan adanya hubungan yang signifikan di antara emosi dan loyalitas. Dalam penelitian ini costumer loyalty digambarkan melalui keinginan pengunjung untuk berkata positif tentang Trans Studio Bandung dan atau merekomendasikan Trans Studio Bandung kepada orang lain.

Berdasarkan penelitian ini, terlihat ambience dan interaction tidak terbukti mempengaruhi variabel joy. 
Dilihat dari total mean variabel ambience sebesar 5,5133 dan total mean variabel interaction sebesar 5,67 yang berarti ambience dan interaction yang ada di Trans Studio Bandung dipersepsikan baik oleh pengunjung, namun kurang dapat dirasakan oleh pengunjung sehingga ambience dan interaction dari Trans Studio Bandung tidak berpengaruh terhadap joy dari pengunjung.

Penelitian ini menunjukkan design berpengaruh secara signifikan terhadap variabel joy. Design merupakan fasilitas fisik yang dapat dilihat dan dirasakan oleh pengunjung. Semakin baik design suatu tempat, semakin jelas konsep yang dapat dirasakan oleh pengunjung. Dilihat dari total mean variabel design sebesar 5,315 yang berarti design dari Trans Studio Bandung dipersepsikan sesuai dengan konsep yang ada. kesesuaian design dari masing-masing konsep dapat dilihat dan dirasakan oleh pengunjung sehingga design Trans Studio Bandung dapat berpengaruh terhadap joy.

Berdasarkan penelitian ini joy berpengaruh signifikan terhadap costumer loyalty. Joy yang dirasakan oleh pengunjung mendorong timbulnya costumer loyalty. Semakin tinggi joy yang dirasakan oleh pengunjung, maka semakin tinggi keinginan pengunjung untuk mengatakan hal positif serta merekomendasikan Trans Studio Bandung kepada orang lain.

Berdasarkan hasil penelitian dijelaskan nilai mean dari A2 (Lighting) mendapat penilaian terendah, yang berarti Trans Studio Bandung perlu lebih meningkatkan pencahayaan yang ada di Trans Studio Bandung. Peningkatan pencahayaan dapat dilakukan dengan menambah varian dari warna lampu, intensitas cahaya, jenis lampu dan tata letak lampu yang ada.

Nilai mean dari I4 (Knowledge) mendapat penilaian terendah, yang berarti Trans Studio Bandung perlu lebih meningkatkan pengetahuan dari staff Trans Studio Bandung. Meningkatkan pengetahuan dari staff Trans Studio Bandung dapat dilakukan dengan melakukan training secara berkala kepada seluruh staff. Pentingnya Training bagi Staff Trans Studio Bandung dikarenakan Trans Studio Banndung selalu mengadakan promo yang berbeda setiap bulannya sehingga staff harus selalu update knowledge mengenai informasi dan promo-promo baru setiap bulan. Selain meningkatkan kemampuan staff, peningkatan pengetahuan dari staff harus diiringi dengan sikap yang lebih interaktif antara staff dan pengunjung.

Berdasarkan hasil penelitian dijelaskan nilai mean dari D2 (Arsitektur) mendapat penilaian terendah, yang berarti Trans Studio Bandung perlu lebih meningkatkan kesesuaian arsitektur dengan setiap zona yang ada di Trans Studio Bandung. Hal ini dapat dilakukan dengan cara memperjelas konsep setiap zona dengan arsitektur yang lebih mendukung konsep yang ada.

Trans Studio Bandung perlu lebih meningkatkan perasaan bersemangat dari pengunjung Trans Studio Bandung, karena berdasarkan hasil penelitian dijelaskan nilai mean dari $\mathbf{J} 2$ mendapat penilaian terendah. Hal ini dapat dilakukan dengan memilih jenis musik yang tepat untuk memacu adrenalin dan menambah wahana yang lebih menarik atau dengan menambahkan lampu yang memiliki efek cahaya sesuai dengan ritme musik yang dimainkan.

Rekomendasi yang diberikan adalah perlu ditambahkan pengukuran dari Atmospheric. Penelitian ini hanya menggunakan satu jenis interaksi saja untuk menjadi konstrak dari Atmospheric. Selain interaksi yang terjadi antara service provider dan pengunjung, masih ada bentuk interaksi lain yang dapat dijadikan pertimbangan sebagai konstrak dari variabel Atmospheric yaitu Interaksi antar pengunjung.

Rekomendasi lain yang diberikan bagi peneliti selanjutnya adalah menambahkan indikator bagi variabel customer loyalty, karena pada penelitian ini ukuran untuk loyalitas pelanggan hanya sebatas keinginan untuk mengatakan hal yang positif dan merekomendasikan kepada orang lain (sesuai jurnal rujukan), sehingga dipenelitian selanjutnya direkomendasikan peneliti untuk menambahkan satu indikator tambahan yaitu kunjungan kembali sebagai indikator dari varibel customer loyalty.

\section{DAFTAR REFERENSI}

Adelmann, P. K. \& Zajonc, R. B. 1989. Facial Efference and the Experience of Emotion. Annual Review and Psychology, 40: 249-280.

Adler, P. S., Riley, P., Kwon, S., Signer, J., Lee, B., \& Satrasala, R. 2003. Performance Improvement Capability: Keys to Accelerating Improvement to Hospitals. California Management Review, 45(2): 12-33.

Bagozzi, R. P. 1997. Goaldirected Behaviors in Marketing: The Role of Emotion, Volition and Motivation. Psychology \& Marketing, 4(3): 309 -313 .

Barsky, J. \& Nash, L. 2002. Evoking Emotion: Affective Keys to Hotel Loyalty. Cornell Hotel and Restaurant Administration Quarterly, 43(1): 39-46.

Bigne', J. E., Andreu, L., \& Gnoth, J. 2005. Theme Park Experience: An Analysis of Pleasure, Arousal and Satisfaction. Tourism Management, 26(6): 833-844. 
Ferdinand, A. 2002. Sctructural Equation Modeling dalam Penelitian Manajemen. Semarang: Badan Penerbit Universitas Diponegoro.

Griffin, J. 1995. Customer Loyaty: How to Earn It How Keep It. New York: Lexington Books.

Groönroos, C. 2001. The Perceived Service Quality Concept - A Mistake? Managing Service Quality, 11(3): 150-152.

Grove, S. J. \& Fisk, R. P. 1997. The Impact of Other Customers on Service Exchange: A Critical Incident Examination of Getting Along. Journal of Retailing, 73(1): 63-85.

Kotler, P. 1973. Atmospherics as a Marketing Tool. Journal of Retailing, 49(4): 48-64.

Levy, M. \& Weitz, B. 2004. Retailing Management. New York: McGraw Hill Companies Inc.

Longino, E. 2007. The Determinants of Sales Organization Effectiveness in Pharmaceutical Industry. USA: Boca Raton.

Lundqvist, L. \& Dimberg, U. 1995. Facial Expressions are Contagious. Journal of Psychophysiology, 9(3): 203-211.

Martin, D., Martin, O. N., Hubbard, S., \& Palmer, A. 2008. The Role of Emotion in Explaining Consumer Satisfaction and Future Behavioural Intention. Journal of Services Marketing, 22(3): 224-236.

Minor, M. S., Wagner, T., Brewerton, F .J., \& Hausman, A. 2004. Rock On! An Elementary Model of Customer Satisfaction with Musical Performances. Journal of Services Marketing, 18(1): 7-18.
Oliver, R. L. 1993. A Conceptual Model of Service Quality and Service Satisfaction: Compatible Goals, Different Concepts. Greenwich, CT: JAI Press.

Otto, J. E. \& Ritchie. J. R. 1996. The Service Experience in Tourism. Tourism Management, 17(3): 165-174.

Sektor Pariwisata Sumbangkan Devisa Negara 9,07 Miliar Dollar. 2012. (http:// ekonomi.tvonenews. tv/berita/view/65414/2012/12/19/sektor_pariwis ata_sumbangkan_devisa_negara_907_miliar_do lar.tvOne, diakses pada tanggal 20 Maret 2013).

Slatten, T., Mehmetoglu, M., Svensson, G., \& Svaeri, S. 2009. Atmospheric Experiences that Emotionally Touch Costumer: A Case Study from Winter Park. Managing Service Quality, 19(6): 721-746.

Søderlund, M. \& Rosengren, S. 2008. Revisiting the Smiling Service Worker and Customer Satisfaction. International Journal of Service Industry Management, 19(5): 552-574.

Strauss, B. \& Neuhaus, P. 1997. The Qualitative Satisfaction Model. International Journal of Service Industry Management, 9(2): 169-188.

Yuan, Y. H. \& Wu, C. 2008. Relationships among Experiential Marketing, Experiential Value and Customer Satisfaction. Journal of Hospitality \& Tourism Research, 32(3): 387-410. 